\title{
The Influence on Livestock Industry and Development Prospect of Eupatorium adenophorum Spreng
}

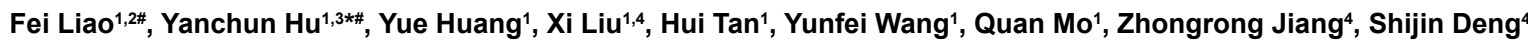

${ }^{1}$ College of Veterinary Medicine, Sichuan Agricultural University, Sichuan Province, Ya an 625014, China

${ }^{2}$ Qiandongnan Prefectural Center for Animal Disease Control and Prevention of Guizhou province, Kaili 556000, China

${ }^{3}$ Key laboratory of Animal Disease and Human Health of Sichuan Province, Sichuan Agricultural University, Ya'an, China

${ }^{4}$ Ganzi Institute of Animal Husbandary, Sichuan Province, Kangding 626000, China

\#Contributed equally

\begin{abstract}
Eupatorium adenophorum Spreng has seriously threatened the sustainable development and the grassland ecosystem of the world livestock industry. This review has elaborated the geographic distribution, chemical constituent, damage to the grassland and livestock industry and ecological influence of Eupatorium adenophorum Spreng. The prevention and control, development and application prospect as feed and medical resources has also been stated.
\end{abstract}

Keywords: Eupatorium adenophorum Spreng; Livestock industry and ecological influence; Prevention and control, Development and application

Eupatorium adenophorum (E. adenophorum) Spreng is a species of flowering plant in the daisy family known by many common names, including eupatory, sticky snakeroot, crofton weed, and Mexican devil. After the introduction as a ornamental plant to USA in 1960s, it has spread worldwide. E. adenophorum Spreng can reproduce both sexually and asexually. It spreads fast, dies fast and has a great adaptation to environment. It is threatening the native biodiversity by its allelopathic competition with other plant species. It contains chemicals such as hemiterpenes, sterides, triterpenes, flavonoid and phenylpropanoids phenol, etc. This essay mainly illustrates and concludes the current research progress about E. adenophorum Spreng.

\section{Distribution}

It is native to Mexico and Costa Rica, but it is known in many other parts of the world as an introduced species such as Europe, Oceania and Asia [1]. Due to the reason that its seed can spread along with the wind, it is an invasive species in many tropical and subtropical countries, including USA, Australia, New Zealand, South Africa, Spain, India, Philippine, Malaysia, Singapore, Indonesia, Papua, New Guinea, Thailand, Burma, Vietnam, Nepal, Pakistan, Pacific Islands and China. It was first inadvertently introduced to Yunnan around 1940 from the China-Burma border. Now it distributes in the Province of Sichuan, Guizhou, Guangxi and Tibet. It still spreads at a speed of $60 \mathrm{~km}$ per year towards East and North. If the spreading trend continues, E. adenophorum Spreng may cover the entire southern Yangzi River area after a century [2].

\section{Main Chemical Constituents and Harm to Livestock Industry}

As reported, several compounds has separated and characterized from E. adenophorum Spreng stem, flowers and leaves, including hemiterpenes, sterides, triterpenes, flavonoid and phenylpropanoids phenol etc (Table 1). Elaborations for harm to animals are as follows: Flowers and leaves of E. adenophorum Spreng contain substances which are with strong local stimulation(especially at skin, mucosa and eyes) and even contact dermatitis, such as butanedioic anhydride and 9-Oxo-10, 11-dehydroageraphorone (generally known as Euptox A) [3]. It is proved that Euptox A is also a liver toxin [4,5], which may lead to icterus, bile duct hyperplasia and expansion, liver cell necrosis, a obvious increase of total bilirubin, alkaline phosphatase, aspartate aminotransferase and alanine aminotransferase. E. adenophorum Spreng's seeds have a huge mass of cilium, which may cause blind if it floats into eyes, especially for horses [6]. E. adenophorum Spreng also contains volatile chemicals such as camphor, bornyl acetate, geranial, citronellal, dimethylsulfide [7]. The stimulus smell would poison horse for the tall-stem and high-density of E. adenophorum Spreng. The pollen and seed contain ageraphorone, which would cause allergic bronchial pneumonia of horses with the symptoms of acute pulmonary edema early of the illness and cerebral hemorrhage later on which caused the final death [8]. The tannin, clavulanic alcohol and lactone can stimulate the mucosa of animal stomach, affecting the digestion system [9].

The invasion of E. adenophorum Spreng may decrease the grass production and livestock number, even lose the grazing value. As reported, under the background of the severe drought, invasive plant E. adenophorum Spreng has spread across the entire Guizhou province caused serious damage to the grassland and livestock. 1.2 billion kilogram grass has been cut down per year, which leads to a 400 million RMB direct lost, Only 3 years after, the coverage of E. adenophorum Spreng in Liangshan Prefecture of Sichuan Province reached to $85 \% \sim 95 \%$ of the entire grassland, and forage grass has reduced to 2400 $\mathrm{kg} \sim 2940 \mathrm{~kg} / \mathrm{hm}^{2}$ which has fallen $70.1 \% \sim 79.36 \%$ [10].

\section{Harm to Eco-system}

After China was invaded by E. adenophorum Spreng, the local eco-system has been seriously damaged which caused enormous loss to Chinese livestock industry, agriculture, forests, natural landscape

*Corresponding author: Yanchun Hu, Sichuan Agricultural University, China, Tel +86 835 2885951; Fax: +86 835 2885302; E-mail: yanchunhu@126.com

Received February 02, 2015; Accepted March 17, 2015; Published March 24 2015

Citation: Liao F, Hu Y, Huang Y, Liu X, Tan H, et al. (2015) The Influence on Livestock Industry and Development Prospect of Eupatorium adenophorum Spreng. J Microb Biochem Technol 7: 057-060. doi:10.4172/1948-5948.1000182

Copyright: (c) 2015 Liao F, et al. This is an open-access article distributed under the terms of the Creative Commons Attribution License, which permits unrestricted use, distribution, and reproduction in any medium, provided the original author and source are credited 


\begin{tabular}{|l|c|c|}
\hline Toxins & \multicolumn{1}{|c|}{ Toxicity } & Distribution \\
\hline 2-deoxo-2-(acetyloxy)-9-oxoageraphorone & Hepatotoxicity & Flowers, leaves, Stem \\
\hline 9-oxo-agerophorone & Hepatotoxicity & Flowers, leaves, Stem \\
\hline 9-oxo-10,11-dehydro-agerophorone & Hepatotoxicity & Flowers, leaves, Stem \\
\hline Butanedioic anhydride & Fkin, Mucosa, Eyes & Howers, leaves, Stem \\
\hline $\begin{array}{l}\text { Camphor } \\
\text { Bornyl acetate } \\
\text { Geranial } \\
\text { Citronellal } \\
\text { Dimethylsulfide }\end{array}$ & Horse & \\
\hline 2-hydroxycoumaric acid & Plant & \\
\hline
\end{tabular}

Table 1: Main toxins and their distribution of E. adenophorum Spreng.

and species diversity. Inhibiting local plants growth and altering the nutrition construction in soil have been declared to be the most harmful factors about E. adenophorum Spreng invasion.

\section{Inhibiting the Growth of Plants}

E. adenophorum Spreng can spread madly in China because there are no natural enemies. It also performs an allelopathy effect, such as ground leaching allelopathy substances, 4,7-dimethyl-1(PorPna-2-ylidene)-1,4,4a,8a-tetrahydronaphthalene-2,6(1H,7H)dione (DTD) and 6-hydorxy-5-isoporpyl-3,8-dimehtyl-4a,5,6,7,8,8ahexahydronaphthalen-2(1H)-one (HHO) [11]. The other two primary allelochemicals (9-Oxo-10,11-dehydroa-geraphorone and 9 b-Hydroxyageraphorone) had been identified in E. adenophorum leachates [12]. These chemicals can cause prominent crowding-out effect to local plants, threatening the native vegetation eco-balance [13]. However, there is a distinction between different species and communities. And the leaves' leach liquor of E. adenophorum Spreng has different effect on the germination rate and seed growth degree of different plants under different environment condition [14]. According to the results, non-gramineous plants are more sensitive to the allelopathy effect than gramineous plants, leguminosae and trees. Single community is more sensitive than multifarious communities [15]. But the allelopathy effect keeps adding up as the concentration of the leach liquor increases. This result may imply the relationship between the allelopathy of E. adenophorum Spreng and its invasion.

Another experiment indicates that o-Coumaric acid is a potent toxin that might play an important role in the competition of $E$. adenophorum with its neighboring plants during its invasion and establishment [16].

\section{Absorbing Soil Nutrition}

E. adenophorum Spreng is able to utilize the abundant available nitrogen, potassium and phosphorus in the soil to compete with the local plants. However, beneficial changes have been made to the soil. That is, invasion can promote the $\mathrm{NH}^{4+}-\mathrm{N}$ and $\mathrm{NO}^{3-}-\mathrm{N}$ level in the soil, reduce the total phosphorus and available phosphorus content, effect microorganism community distribution, improve the soil nutrition level and the enzymatic activity, and increase the number of microorganism [17]. These changes can help E. adenophorum Spreng surviving on an infertile land and providing a convenient way for its invasion while may cause the grassland degeneration and the outcome of crops or trees reduction [18].

\section{Prevention and Control}

\section{Chemical and physical control}

Chemical prevention is to utilize selective chemicals which are sensitive to E. adenophorum Spreng to spray plants in order to make them withered. 2,4-D, 2,4-D butyl ester, 2,4,5-T, tebuthiuron, sulfometuron, sodium chlorate, glyphosate isopropylamine, picloram, sulfonylurea and glyphosate were reported as effective chemicals [19]. The sulfometuron-methyl and saflufenacil were strongly inhibited flowering and fructification of E. adenophorum [20]. Some study showed that using sensitivity to control E. adenophorum growth was feasible and effective [21]. But these chemicals have some limitations such as harm to other plants, large dosage, influence in weather factors and not thorough effect.

Physical prevention is to utilize human labors and machines to prevent invasive plants. But manual weeding takes a lot of labor work and not as much efficiency. Mechanical weeding is much faster, but the success rate is quite low. And another drawback for using machine is some plants grow on the mountain and hillside, where machines can hardly work.

\section{Biological Control}

Biological prevention is to use the competitive relation of other plants, E. adenophorum Spreng natural enemies or microbial to conduct prevention. Two primary methods are vegetation coverage and natural enemy prevention.

\section{Vegetation cover}

Present grasses that have been proven effective for vegetation cover are Pennisetum hydridum, Herba Setariae Viridis, Ryegrass, Paspalum natatum, Imperata cylindrica, Alfalfa, Imperatoria etc., and trees are Masson pine, Semen Castaneae Mollissimae, Eucalyptus etc., among which the best plant is Masson pine [22]. Although these plants do have made progress in the plant displacement, whether or not they have allelopathy effect to E. adenophorum Spreng needs further study. Herba Artemisiae Annuae and Herba Junci Setchuensis have allelopathy effect which helps it growing in the E. adenophorum Spreng invasive areas, meanwhile, affect E. adenophorum Spreng seed growing and expansion negatively to some extent [23]. This shows while ecologically controlling E. adenophorum Spreng and restoring local vegetation, we should choose plants that have the same resources use mode but different resources with E. adenophorum Spreng. Multi-species combination can build multi-function community, thus, the ecological superiority of $E$. adenophorum Spreng will be pillaged and eventually remain the sustainable development of the ecosystem.

\section{Natural enemy control}

Fungus and insects like Procecidochares utilis and Dihammus Cervinus can control the growth of E. adenophorum Spreng effectively. Cercospora mikaniacola, Alternaria alternata eupatori, Mycovellosiella eupatorii-edomti, leaf spot fungus, Ageratum conyzoides Mirisporites can cause leave spot disease, making stem and leaves being infected and eventually inhibiting the growth [24]. In addition, Kunming 
Institute of Botany has found that truffle may also inhibit the growth of E. adenophorum Spreng, which provide another way of prevention. Procecidochares utilis can affect the germination rate of $E$. adenophorum Spreng seeds, but it does no effect on the latter growth. After plant displacement, the new ecological environment affects not only the E. adenophorum Spreng stem height, but the parasitism rate of Procecidochares utilis. Another finding is 3 different types of parasitic wasp have considerable high parasitism rate to Procecidochares utilis. These factors are the reason why utilizing Procecidochares utilis to control the growth is not as effective. Dihammus Cervinus can also cause mechanical damage or even death to E. adenophorum Spreng. However, the root remained in the soil may grow back into an intact plant next year. And a native insect known as Ortheziidae in Yunnan, Yingjiang, and this type of insect like gathering at the stem junction sucking the juice, making the plants [25].

\section{Microbial control}

Comparative studies showed that mycelium of Phaeoramularia sp. was as pathogenic as conidia of crofton weed (Ageratina adenophora) and that the former may have potential for further development as a mycoherbicide [26]. However, its low growth rate has cut off the utilization prospect. Another study showed that mycelia of Alterttaria alternate (Fr.) Keissler Strain 501 which separated from $E$. adenophorum were produce herbicides to slow down the invasion rate [27]. So far, there is no more effective method to control the growth and breeding about E. adenophorum. Biodegradation of the main toxin named Euptox A was performed by us. And 3 strains of bacteria, Stenotrophomonas sp. XC-07, Klebsiella sp. XC-08 and Pseudomonas sp. XC-09, separated from E. adenophorum leaves, deposit soil and the rumen of native goat, were proved to have the degrading rates of $91.2 \%, 94.3 \%$ and $93.2 \%$ respectively in the $45 \mathrm{mg} / \mathrm{L}$ Euptox A in 24 $\mathrm{h}$, determined by TLC and HPLC [28]. The overall results may lay the foundation of preventing E. adenophorum invasion and imply potential applications for the optimal approach to the utilization, improvement and feed production.

\section{Applications}

\section{Feed resources}

E. adenophorum Spreng has a wide distribution area among China. This plant grows fast and spreads fast. The nutrition it contains such as protein, microelement and fat are above average level among grass. If E. adenophorum Spreng could be made into feed products, it would bring great significance to remitting the current shortage of feed resources. Numerous researches have proved across the world that detoxified E. adenophorum Spreng is an idea feed material. For instance, the degradation rate of the organic substances inside $E$. adenophorum Spreng increase $8 \%$ after plants being solarized, after the feed being mixed with both E. adenophorum Spreng and Ficus cunia, goats' grazing rate is prominently increased [29]. After 4 weeks feeding, no obvious negative effect to the body weight. Feeding goats with $20 \mathrm{~g}$ feed which has been mixed with E. adenophorum Spreng and Folium mori (4:6) after being solarized can promote the rumen digestion of goats, decrease rumen gas production, adjust the structural proportion of formic acid, acetic acid and propionic acid, improving the rumen protein production [30]. And added 20\%-40\% E. adenophorum Spreng which has been detoxified with Aspergillus flavus and Aspergillus to feed the goats, it turned out with no negative effect. All the research above has testified that the E. adenophorum Spreng has the potential as a kind of feed resources.

\section{Medical resources}

E. adenophorum Spreng can not only become the feed resource, it also contains considerable chemical substances with pharmacological effects such as anti-Inflammatory potential [31], acaricidal activity [32, 33], antioxidant activity of ethanolic leaf extract [34] and antifungal of activity of cadinene sesquiterpenes [35]. Flowers and leaves extract of E. adenophorum Spreng which were extracted by alcohol and acetone could control chicken coccidiosis disease [36]. The inflorescence oil showed higher antibacterial activity against Klebsiella pneumoniae, and the root oil was more effective against Staphylococcus aureus [37]. The study has found that E. adenophorum Spreng toxin has positive effects in the chicken coccidiosis disease treatment. And there were reported that E. adenophorum Spreng contains chemicals like volatile oils which can be used in producing essence, antibiotics and pesticides [38]. The cadinene sesquiterpenes of cadinan-3-ene-2,7dione have highly inhibitory towards $S$. rolfsii (ED50 $181.60 \pm 0.58$ $\mu \mathrm{g} / \mathrm{ml}$ ) and $R$. solani (ED50 $189.74 \pm 1.03 \mu \mathrm{g} / \mathrm{ml}$ ). Our laboratory has already extracted Euptox A from E. adenophorum Spreng and declared a national invention patent. We proved that Euptox A had highly acaricidal activity against $S$. scabiei and $P$. cuniculi in vitro and in vivo $[39,40]$ and Euptox A presented significanty antitumor activity against the human lung cancer A549, HeLa and Hep-2 cell lines in vitro in a dose-dependent manner $[41,42]$. Other studies have also found that E. adenophorum Spreng contains a great amount of chlorogenic acid known as "Botanic Gold" and the extraction rate is $1 \%$. Chlorogenic acid is an important biological active substance with functions like antibacterial, antivirus, elevating the leucocyte, protecting liver and bile, antineoplastic, antihypertensive, hypolipidemic, eliminating radicals, antioxidative and stimulating the central nerve system [43]. It also can be made into decent health-care product.

\section{Chemical material resources}

As a chemical raw material, E. adenophorum Spreng is a natural dye, which after being boiled under higher temperature helps turn items into a bright yellow color, without fading. E. adenophorum Spreng is seen extensively used in ethnic tie-dye industry and can also be of quality source for fragrance making. The geranyl butyrate and (-)-Caryophyllene Oxide found in E. adenophorum Spreng can be fermented with numerous yeasts to create xylitol [44]. The $E$. adenophorum can be as Rotten Fertilizer Application in agricultural production [45], and can be as activated carbon and high calorific value gas [46]. Other benefits of E. adenophorum Spreng include expelling mosquito effects.

\section{Prospect}

Although the results have manifested E. adenophorum Spreng has done massive damage to husbandry industry and eco-system, only the scientific and dialectical methods we take, the invasion of E. adenophorum Spreng be eventually conquered and make great economic value for us.

\section{References}

1. Auld BA (1969) The distribution of Eupatorium adenophorum Spreng on the far north coast of New South Wales. J Proc R Soc New South Wales 59-61.

2. Lu ZJ, Ma KP (2006) Spread of the exotic croftonweed (Eupatorium adenophorum) across southwest China along roads and streams. Weed Sci 54: 1068-1072.

3. Wang YC, Zhao BY, Fan ZF, Fan YY, Tan CJ (2005) The Advance in Eupatorium adenophorum Spreng and Its Damage. Progress In Vet Med 26: 45-48.

4. Bhardwaj R, Singh A, Sharma OP, Dawra RK, Kurade NP, et al. (2001) 
Citation: Liao F, Hu Y, Huang Y, Liu X, Tan H, et al. (2015) The Influence on Livestock Industry and Development Prospect of Eupatorium adenophorum Spreng. J Microb Biochem Technol 7: 057-060. doi:10.4172/1948-5948.1000182

Hepatotoxicity and cholestasis in rats induced by the sesquiterpene, 9-oxo10,11-dehydroageraphorone, isolated from Eupatorium adenophorum. J Biochem Mol Toxicol 15: 279-286.

5. Katoch R, Sharma OP, Dawra RK, Kurade NP (2000) Hepatotoxicity of Eupatorium adenophorum to rats. Toxicon 38: 309-314.

6. O'Sullivan BM (1985) Investigations into Crofton weed (Eupatorium adenophorum) toxicity in horses. Aust Vet $\mathrm{J}$ 62: 30-32.

7. Da PF, Hong YQ (2003) Damage characteristics of Imperata cylindrical and its recent development of research and utilization. Forest Inventory and Planning. 28: 95-98.

8. Yan QS, Yang J, Li HM, Cao AC, Chen QH, et al. (2006) Advances in the studies on the chemical components and bioactivity of Eupatorium adenophorum Spreng as a intruding species. J Beijing Normal University 42: 70-73.

9. Wang ZF, Li BP (2007) Parasitism of native parasitoids on Procecidochares utilis Stone (Tephritidae, Diptera), a biocontrol agent against the invasive exotic weed Eupatorium adenophorum Spreng (Compositae) in southwest China. Chin J Biol Control 23:115-118.

10. Wan F1, Liu W, Guo J, Qiang S, Li B, et al. (2010) Invasive mechanism and control strategy of Ageratina adenophora (Sprengel). Sci China Life Sci 53: 1291-1298.

11. Yang GQ, Wan FH, Liu WX (2008) Allelopathy research progress on an invasive weed, Ageratina adenophora Sprengel. Acta Phytophylacica Sinica 35: 463-468.

12. Zhu X1, Zhang J, Ma K (2011) Soil biota reduce allelopathic effects of the invasive Eupatorium adenophorum. PLoS One 6: e25393.

13. Tan WB, Zhang DH, Xiong CM, Gong XY, Jiang J, et al. (2010) Study on the Allelopathy of Eupatorium adenophorum Spreng on Ten Species of Plants. J Anhui Agr Sci 38: 4412-4416

14. Zhong S, Duan XH, Kui JX (2007) Allelopathy of Eupatorium adenophorum on germination and seedling growth of 16 pastures. Acta Prataculturae Sinica 16:81-87.

15. Jiang ZL, Liu WX, Wan FH, Li ZY (2008) Effects of Ageratina adenophora (Spreng.) invasion on soil nutrient properties and their seasonal dynamics. J Agro-Environ Sci 27: 267-272.

16. Zheng G, Jia Y, Zhao X, Zhang F, Luo S, et al. (2012) o-Coumaric acid from invasive Eupatorium adenophorum is a potent phytotoxin. Chemoecology 22 131-138.

17. Liu C, Feng YL, Tian YH (2007) Effects of Eupatorium adenophorum Sprenge invasion on soil enzyme activities and physical and chemical factors. Bull Botanical Res 27:729-735.

18. Peng H, Gui FR, Li ZY, Li J, Wan FH (2010) Competition effect of Imperata cylindrica to Ageratina adenophora. Chin J Ecol 29:1931-1936.

19. Wu D, Yao Z, Hui Z (2003) Contorol and Utilization of the Poisonous Weed Eupatorium adenophorum. Agric Technol 23:23-28.

20. Zhu WD, Cao AC Yan DD, Li L, Liu XY, et al. (2013) Evaluation the efficacy and influence of herbicides on flowering and fruitification of Eupatorium adenophorum Spreng Ecology and Environmental Sciences 22:850-825.

21. Hua JS (2013) Effect evaluation on quick killing of Eupatorium adenophorum of sensitive plant growth inhibitor. Guangdong Agricultural Sciences 6:93-95.

22. Zhang RX (2011) Biological Substitution Effects of Eupatorium adenophorum with Different Forage Species. J Anhui Agric Sci 39: 19855-1985.

23. Liu SC (2010) Allelopathic Effects of Associated Herbs Artemisia carvifolia and Eulaliopsis binata on Eupatorium adenophorum Sprengel J Anhui Agric Sci 38 : 6167-6173.

24. Buccellato L, Byrne MJ, Witkowski ETF (2012) Interactions between a stem gall fly and a leaf-spot pathogen in the biological control of Ageratina adenophora. Biol Control 61: 222-229.

25. Xu J, Liu ED, Xiang CL, Chen L, Peng H (2011) Orthezia quadrua (Homoptera: Ortheziidae): a native natural enemy of Ageratina adenophora and Chromolaena odorata. J Yunnan Agric University 26: 577-579.

26. Wang F, Summerell BA, Marshail DR, Auld BA (1997) Inoculum production of Phaeoramularia, a potential mycoherbicide for croftonweed. Aust Plant Pathol 26:173-178.
27. Qiang S, Zhu Y, Summerell BA, Li Y (2006) Mycelium of Alternaria alternata as a potential biological control agent for Eupatorium adenophorum. Biocontro Sci Technol 16: 653-668.

28. Liao F, Wang $Y$, Huang $Y$, Mo Q, Tan $H$, et al. (2014) Isolation and identification of bacteria capable of degrading euptox $A$ from Eupatorium adenophorum Spreng. Toxicon 77: 87-92

29. Rymer C (2008) The effect of wilting and soaking Eupatorium adenophorum on its digestibility in vitro and voluntary intake by goats. Anim Feed Sci Technol 141: 49-60.

30. Sahoo A, Singh B, Sharma OP (2011) Evaluation of feeding value of Eupatorium adenophorum in combination with mulberry leaves. Livestock Sci 136: 175-183.

31. Chakravarty AK, Mazumder T, Chatterjee SN (2011) Anti-inflammatory potential of ethanolic leaf extract of Eupatorium adenophorum Spreng. Through Alteration in Production of TNF-a, ROS and expression of certain genes. Evidence-Based Complementary and Alternative Med 2011

32. Nong X, Ren YJ, Wang JH, Xie Y, Fang CL, et al. (2013) Clinical efficacy of botanical extracts from Eupatorium adenophorum against the Sarcoptes scabiei (Sarcoptidae: Sarcoptes) in rabbits. Vet Parasitol 195: 157-164.

33. Seddiek SA, Khater HF, El-Shorbagy MM, Ali AM (2013) The acaricidal efficacy of aqueous neem extract and ivermectin against Sarcoptes scabiei var. cuniculi in experimentally infested rabbits. Parasitol Res 112: 2319-2330.

34. Kundu A, Saha S, Walia S, Ahluwalia V, Kaur C (2013a) Antioxidant potentia of essential oil and cadinene sesquiterpenes of Eupatorium adenophorum. Toxicol Environ Chem 95: 127-137.

35. Kundu A, Saha S, Walia S, Shakil NA, Kumar J, et al. (2013) Cadinene sesquiterpenes from Eupatorium adenophorum and their antifungal activity. $J$ Environ Sci Health B 48: 516-522.

36. Yang J, Wang R, Lv R, Zhou D, Duan G, et al. (2012) Anticoccidial activity of Eupatorium adenophorum extracts against chicken coccidian oocysts. Journal of Animal and Veterinary Advances. 11: 1255-1257

37. Ahluwalia V, Sisodia R, Walia S, Sati OP, Kumar J, et al. (2014) Chemica analysis of essential oils of Eupatorium adenophorum and their antimicrobial, antioxidant and phytotoxic properties. Journal of pest science 87: 341-349.

38. Kurade NP, Jaitak V, Kaul VK, Sharma OP (2010) Chemical composition and antibacterial activity of essential oils of Lantana camara, Ageratum houstonianum and Eupatorium adenophorum. Pharm Biol 48: 539-544.

39. Hu Y, Liao F, Hu Y, Luo B, He Y, et al. (2014) Clinical efficacy of 9-oxo-10,11 dehydroageraphorone extracted from Eupatorium adenophorum against Psoroptes cuniculi in rabbits. BMC Vet Res 10: 306.

40. Liao F, Hu Y, Tan H, Wu L, Wang Y, et al. (2014) Acaricidal activity of 9-oxo10,11-dehydroageraphorone extracted from Eupatorium adenophorum in vitro. Exp Parasitol 140: 8-11.

41. Liao F, Hu Y, Wu L, Tan $\mathrm{H}$, Luo B, et al. (2015) Induction and mechanism of HeLa cell apoptosis by 9-oxo-10,11-dehydroageraphorone from Eupatorium adenophorum. Oncol Rep 33: 1823-1827.

42. Liao F, Hu Y, Wu L, Tan H, Zuo Z, et al (2014a) Antitumor Activity in vitro by 9-Oxo-10,11-dehydroageraphorone Extracted from Eupatorium adenophorum. Asian Journal of Chemisity 26: 7321-7323.

43. Sato Y, Itagaki S, Kurokawa T, Ogura J, Kobayashi M, et al. (2011) In vitro and in vivo antioxidant properties of chlorogenic acid and caffeic acid. Int J Pharm 403: $136-138$

44. Padalia RC, Bisht DS, Joshi SC, Mathela CS (2009) Chemical Composition of the Essential Oil From Eupatorium adenophorum Spreng. J Essent Oil Res 21: $522-524$.

45. Liu XL, Hu JZ, Bai J, Liu XY, Zhong GH, et al. (2014) Study on the Detoxification Process of Eupatorium adenophorum Spreng and its Rotten Fertilizer Application in Allium schoenoprasum L. Chinese Agricultural Science Bulletin 30: $149-153$

46. Zheng ZQ, Xia HY, Peng JH, Zhang LB (2014) Study on Production of Activated Carbon and High Calorific Value Gas from Eupatorium Adenophorum. Materials Review 28: 39-43. 